\title{
The Difference in Learning Achievement in Natural Science Between Students Who Used Photographic Picture and Those Who Used Video
}

\author{
Fitria Wardani \\ Biology Education Study Program \\ Universitas Mataram \\ Mataram, Indonesia
}

\author{
Khairuddin Khairuddin* \\ Biology Education Study Program \\ Universitas Mataram \\ Mataram, Indonesia \\ khairuddin.fkip@unram.ac.id
}

\author{
I Wayan Merta \\ Biology Education Study Program \\ Universitas Mataram \\ Mataram, Indonesia
}

\begin{abstract}
This research aims to determine the difference between the application of photographic picture and video in student learning outcomes on Natural Science at Class VIII of Junior High School 23 Mataram in academic year 2017/2018. A randomized factorial design was used in this research. The population was all class VIII students. Population sampling technique was used in which class VIII A served as the experimental class I and class VIII B as the experimental class II. The instruments used in this research were objective tests. The data from the pre-test and post-test results in experimental class I shows the mean values of 42.16 and 71.29 and the results of pre-test and post-test in experimental class II indicated the mean value of 37.04 and 64.96 , respectively in which the results were analyzed by using a t-test with a significant level of $5 \%$. These results indicate that there is no difference in student learning outcomes by the use of a photographic picture and video in natural science learning at class VIII of SMP 23 Mataram academic year 2017/2018.
\end{abstract}

Keywords - photographic picture, video, students' learning outcome.

\section{INTRODUCTION}

Regulation Number 20 of 2003 concerning the national education system, article 1 paragraph 1 stated that "Education is a conscious and planned effort to create an atmosphere of learning and learning process so that students actively develop their potential to have religious-spiritual strength, self-control, personality, intelligence, noble character, and the skills needed by themselves, the people of the nation and the nation".

Based on this regulation, it can be said that education is a learning process directed at the development of students to have spiritual strength, self-control, personality, intelligence, noble character, and the skills needed by themselves, society, nation, and state.

The nature of science is the study of phenomena through a series of processes. This process is known as a scientific process that is built on scientific attitudes and the results are manifested as scientific products. Scientific products are composed of the three most important components in the form of concepts, principles, and theories that apply universally. "Characteristics of natural learning are the teachers should be able to create active, effective, and fun learning that aims to facilitate students in understanding the concepts. This can be done by using picture learning media and video media. The use of instructional media makes abstract things more concrete and provides an interesting learning atmosphere [1].
Based on the means of science learning outcomes and student activeness, it is known that for groups that were taught using video as a learning media had a higher learning outcome compared to those that were taught without using video [2]. The more attractive the media look, the more motivated students will learn which then influences student learning outcomes. Learning media consisting of text, images, animation, and sound, are very interesting and interactive to be used as learning media in schools [3]. Photography as a teaching media can be used in learning biology [4] and can increase effectiveness in learning [5], [6].

Video as a teaching media has several advantages, namely: 1) able to explain the existence of a process, phenomenon, or event, 2) able to enrich the explanation when integrated with other media such as text or images, and 3 ) users can do repetition on certain parts [7].

The use of photographic pictures and videos as teaching media are suitable to be used in Junior High School 23 Mataram. The results of observations indicated that students were more active when given something new and less active when taught monotonously and teacher-centered. This affected student learning outcomes. The results of observations indicated that the means of learning outcomes of Pure General Deuteronomy of grade VIII when they were still on grade VII were 59.45 and 57.15 .

\section{METHOD}

This research was conducted at SMP Negeri 23 Mataram in the odd semester of the 2017/2018 school year. This research is a randomized factorial design in nature. The population in this study were all students of class VIII at junior school 23 Mataram in the academic year 2017/2018 with a total population of 49 people which is divided into two classes. Therefore, population sampling technique was used. Student achievement test data and questionnaire responses obtained were analyzed using statistical tests. The data on learning outcomes tests and questionnaires for student responses were analyzed by using statistical tests. The data analysis covers the normality test, a homogeneity test, and a hypothesis test, with a significance level of $5 \%$.

\section{RESULTS AND DISCUSSION}

The results of pre-test and post-test can be seen in the following figure: 


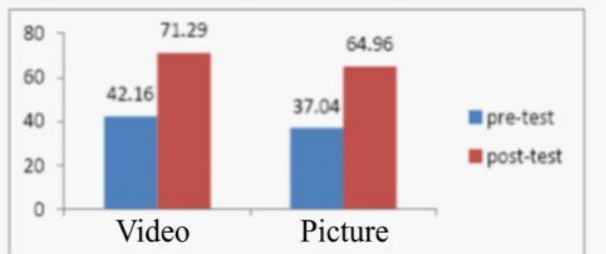

Fig. 1. Comparison of Pre-Test and Post-Test Learning Outcomes

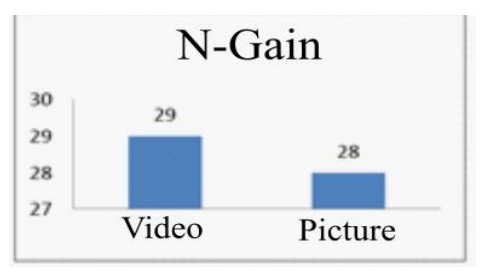

Fig. 2. Comparison of N-Gain

Based on the data obtained, there is an increase in learning outcomes. The mean value of the class taught by using video as teaching media increased from 42.16 to 71.29 . While the class taught by using pictures, the mean value increased from 37.04 to 64.96. The hypothesis of this research was tested three times by using Microsoft Excel 2007. The t-test of the pre-test score indicated that the t-value of 2.11 which is higher than the t-table 1.67. Therefore, it can be concluded that there are differences in the learning outcomes of the Natural Sciences class that was taught by using pictures and videos as learning media. The t-test of the post-test score indicated that the t-value of 2.14 which is higher than the t-table. Therefore, it can be concluded that there are differences in learning outcomes of science using photographic pictures and videos as teaching media. The $\mathrm{N}$ gain score tested with a t-test indicated that the t-value is equal to 1.03 and the t-table with a significance level of $5 \%$ with the degree of freedom of 47 is 1.67 . Since the t-value is lower than the t-table, Ho is accepted and $\mathrm{Ha}$ is rejected which means that there is no difference in science learning outcomes that were taught by using photographic picture and video as learning media. This happens because the effectiveness of learning is not maximal. This result is contrary to the research conducted by [8], which states that the use of video as learning media can be said to be more effective and can create an interesting, pleasant learning atmosphere, so students can better understand the material presented and obtain optimal learning outcomes. Other researchers conducted by [9] and [10] also stated that the use of video as learning media had a significant effect on student learning outcomes in which video media displayed focused students' attention on the material presented. The results of the research conducted by [11] indicated that there is a relation of learning media using video to student learning outcomes. Interactive multimedia-based learning has been judged to be theoretically feasible in learning. Another income said that Web media was suitable to be used as learning media [12].

The use of video as a media can be more effective in the teaching and learning process. This is supported by the results of research which says that the development of instructional video as a media with the ASSURE model in Mathematics subjects make learning to be more effective [13]. The effectiveness of the media is based on the data of student responses, $91.6 \%$ gave a positive response to multimedia-based learning media [14]. The application of multimedia-based learning has a positive effect on increasing motivation and learning outcomes [15], [16]. The results indicated that the learning media based on Augmented Reality on the subject of optical devices meets the requirements of very good quality to be used as a supporting medium in learning activities [17].

It is well known that students' science learning outcomes that use interactive learning media are more effective when compared to disusing it [18], [19]. Other experts have concluded that video-based learning is appropriate for the learning process [20].

The similarity outcomes of the learning which was taught by using photographic picture and video as learning media were caused by the relatively small score difference in which the video class is 71.29 and the photographic picture class is 64.96. Some other factors include: the teaching method, according to [21], and [22], the poor quality of the teacher's teaching method will affect student's learning. According to Slameto, learning interest has a great influence on learning outcomes, with the arising of one's interest in learning will stimulate desires that are accompanied by the attention and activeness of students in the classroom. Related to this statement the use of video and picture as learning media can increase the attention and activeness of students in the classroom, this is shown by the focus attention of students when videos and pictures are given during the learning process and asking questions when given the opportunity. The statement is in line with [23], that stated the benefits of learning media in student learning processes are as follows: first, learning media can clarify the presentation of messages and information to facilitate and improve the process and learning outcomes. Second, learning media improve and direct the student's attention so that it leads to learning motivation. Third, the learning material will be clearer in meaning so that it is better understood by students and enables them to master and achieve learning objectives.

\section{CONCLUSION}

Based on the results of the research and discussion, it can be concluded that there is no difference in learning outcomes that were taught by using photographic pictures with video as learning media in Biological Science subject on class VIII at Junior High School 23 Mataram Academic Year 2017/2018.

It is expected that further researchers will conduct research with different materials.

\section{REFERENCES}

[1] M. P. Trianto, "Mendesain model pembelajaran inovatif-progresif," Jakarta: Kencana, 2009.

[2] D. Yunita and A. Wijayanti, "Pengaruh Media Video Pembelajaran Terhadap Hasil Belajar IPA Ditinjau dari Keaktifan Siswa," SOSIOHUMANIORA J. Ilm. Ilmu Sos. dan Hum., 2017, doi: 10.30738/sosio.v3i2.1614.

[3] J. Kuswanto and F. Radiansah, "Media Pembelajaran Berbasis Android pada Mata Pelajaran Sistem Operasi Jaringan Kelas XI," An Nabighoh J. Pendidik. dan Pembelajaran Bhs. Arab, 2018, doi: 10.32332/annabighoh.v20i01.1131.

[4] R. Primasari, Z. Zulfiani, and Y. Herlanti, "Penggunaan media pembelajaran di madrasah aliah negeri se-Jakarta Selatan," Edusains, vol. 6 , no. 1 , pp. 67-72, 2014

[5] H. Hilmi, "Efektivitas Penggunaan Media Gambar dalam Pembelajaran Bahasa Arab,” Lantanida J., 2017, doi: 10.22373/lj.v4i2.1885 
[6] M. D. Pradana, "Pengembangan Media Tutorial Pembelajaran Mata Kuliah Media Fotografi Pembelajaran," EDUDEENA J. Islam. Relig. Educ., vol. 2, no. 1, 2018.

[7] M. Munir, "Multimedia konsep \& aplikasi dalam pendidikan," Bandung. CV. Afabeta, 2012.

[8] T. A. T. Nugroho, "Pengaruh Media Video Pembelajaran Terhadap Keterampilan Proses dan Hasil Belajar IPA di Kelas V SD Negeri Rejowinangun 1 Yogyakarta," BASIC Educ., vol. 4, no. 6, 2015

[9] S. Sampurna, "Pengaruh Penggunaan Media Gambar dan Video Terhadap Hasil Belajar Bahasa Arab di Kelas II MIN Pemurus Dalam Banjarmasin," 2017.

[10]A. Busyaeri, T. Udin, and A. Zaenudin, "Pengaruh Penggunaan Video Pembelajaran Terhadap Peningkatan Hasil Belajar Mapel Ipa Di Min Kroya Cirebon," Al Ibtida J. Pendidik. Guru MI, 2016, doi 10.24235/al.ibtida.snj.v3i1.584

[11]T. Albaniah, "Hubungan Penggunaan Media Video Pembelajaran Dengan Hasil Belajar Siswa Pada Mata Pelajaran Matematika Kelas IV SDN 76/1 Sungai Buluh,” E-Print, 2014, [Online]. Available: http://ecampus.fkip.unja.ac.id//eskripsi/data/pdf/jurnal_mhs/artikel/A1D10913 6.pdf.

[12]I. M. Amin and S. Sapir, "Pengembangan Media Pembelajaran Berbasis Web Hypertext Markup Language (Html) Pada Matapelajaran Ekonomi Materi Bank Sentral Siswa Kelas X Ips Sman 1 Gondanglegi Kabupaten Malang Semester Genap Tahun Pelajaran 2017/2018," J. Pendidik. Ekon., vol. 11, no. 2, pp. 143-150, 2018.

[13]B. Purwanti, "Pengembangan Media Video Pembelajaran Matematika dengan Model Assure," J. Kebijak. dan Pengemb. Pendidik., 2015.

[14]M. Rasyid, A. A. Azis, and A. R. Saleh, "Pengembangan Media Pembelajaran Berbasis Multimedia dalam Konsep Sistem Indera pada Siswa Kelas XI SMA,” J. Pendidik. Biol., vol. 7, no. 2, pp. 69-80, 2017.

[15]G. Kartikasari, "Pengaruh Media Pembelajaran Berbasis Multimedia Terhadap Motivasi Dan Hasil Belajar Materi Sistem Pencernaan Manusia: Studi Eksperimen pada Siswa Kelas V MI Miftahul Huda Pandantoyo," J. Din. Penelit., 2016, doi: 10.21274/dinamika.2016.16.1.59-77.

[16]F. A. Rha'ifa, K. Khairuddin, and I. W. Merta, "Perbedaan Hasil Belajar IPA Biologi Menggunakan Model Reciprocal Learning dan Problem Based Learning," J. Pijar Mipa, vol. 14, no. 1, pp. 107-112, 2019.

[17]W. M. Putri, F. Bakri, and A. H. Permana, "Pengembangan media pembelajaran berbasis multimedia augmented reality pada pokok bahasan alat optik," in Prosiding Seminar Nasional Fisika (EJournal)(5), SNF2016-RND, 2016.

[18]N. Annisa and N. Simbolon, "Pengembangan Media Pembelajaran Interaktif Ipa Berbasis Model Pembelajaran Guided Inquiry Pada Materi Gaya Di Kelas Iv Sd Negeri 101776 Sampali," Sch. Educ. J. PGSD FIP UNIMED, 2018, doi: 10.24114/sejpgsd.v8i2.10199.

[19]M. A. Fauzan and D. Rahdiyanta, "Pengembangan Media Pembelajaran Berbasis Video pada Teori Pemesinan Frais," J. Din. VOKASIONAL Tek. MESIN, 2017, doi: 10.21831/dinamika.v2i2.15994.

[20]I. D. Kurniawati and S.- Nita, "Media Pembelajaran Berbasis Multimedia Interaktif Untuk Meningkatkan Pemahaman Konsep Mahasiswa," DOUBLECLICK J. Comput. Inf. Technol., 2018, doi 10.25273/doubleclick.v1i2.1540

[21]Y. Febrianti, K. Khairuddin, and M. Yamin, "Perbedaan Hasil Belajar Siswa Pada Penggunaan Model Pembelajaran Problem Based Learning Dengan Model Pembelajaran Guided Discovery Learning Pada Mata Pelajaran IPA Terpadu," J. Pijar Mipa, vol. 14, no. 3, pp. 148-153, 2019.

[22] Slameto, Belajar dan Faktor-faktor yang Mempengaruhinya. Bina Aksara, 1988.

[23]N. Sudjana and A. Rivai, "Media pengajaran," Bandung sinar baru Algensindo, 2010. 